\title{
Towards the development of the first permanent volcano observatory in Argentina
}

\author{
Sebastian Garcia ${ }^{\star \alpha}$, Gabriela Badi ${ }^{\alpha, \beta}$ \\ ${ }^{\alpha}$ OAVV, Servicio Geológico Minero Argentino (SEGEMAR), Av. General Paz 5445 (colectora) Parque Tecnológico Miguelete \\ (Edificio 25), San Martin, Buenos Aires, Argentina. \\ $\beta$ Dpto. de Sismología, Facultad de Cs. Astronómicas y Geofísicas, Universidad Nacional de La Plata, Av. Centenario s/n, Paseo del \\ Bosque, La Plata, Argentina.
}

\begin{abstract}
Argentina is a country that presents a complex situation regarding volcanic risk, where a total of 38 volcanoes are considered active. Although Argentina has no major cities close to these volcanoes, the continuous increase in economic activity and infrastructure near the Andean Codillera will increase exposure to volcano hazards in the future. Further, volcanic activity on the border between Argentina and Chile poses a unique challenge in relation to volcano monitoring and the management of volcanic emergencies. Additionally, due to atmospheric circulation patterns in the region (from West to East), Argentina is exposed to ashfall and ash dispersion from frequent explosive eruptions from Chilean volcanoes. Considering this, the Servicio Geológico Minero Argentino (SEGEMAR) decided to create and implement a Volcanic Threat Assessment Program, which includes the creation of the the first permanent volcano observatory for the country, the Observatorio Argentino de Vigilancia Volcánica (OAVV). Previously the Decepcion Island volcano observatory was created as a collaboration between the Instituto Antártico Argentino (IAA) and the Museo Nacional de Ciencias Naturales (MNCN) from the Consejo Superior de Investigaciones Cientificas (CSIC).
\end{abstract}

Este artículo está disponible en español: https://doi.org/10.30909/vol.04.S1.2148 [PDF ES].

\section{INTRODUCTION}

Volcanic activity in continental Argentina is principally linked to the Andean volcanic arc along the Pacific margin. Here, subduction of the Nazca and Antarctic plates beneath the South American plate controls the occurrence of volcanism, which is distributed in three volcanic zones [Barazangi and Isacks 1976; Jordan et al. 1983; Isacks et al. 1986; Davidson and de Silva 1995; Allmendinger et al. 1997; Ramos et al. 2002; Stern 2004]. To the north, the southern end of the Central Volcanic Zone (CVZ) extends from 16 to $28^{\circ} \mathrm{S}$ and includes the active volcanic centers of the AltiplanoPuna region [Coira et al. 1993; Kay et al. 1994]. The Southern Volcanic Zone (SVZ) includes volcanoes between 33 and $46^{\circ} \mathrm{S}$ and is the most active zone. At the southern tip of the continent, the Austral Volcanic Zone (AVZ, $\left.49-56^{\circ} \mathrm{S}\right)$ is associated with the subduction of the Antarctic plate. The AVZ is characterized by low subduction velocity and the occurrence of few and isolated volcanic centers [Stern and Kilian 1996]. Two gaps in the active volcanic arc are observed along this segment of the Andes: one between the CVZ and the SVZ $\left(28-33^{\circ} 15^{\prime} \mathrm{S}\right)$, known as the Pampean flatslab segment [Jordan et al. 1983; Ramos et al. 2002], and another between the SVZ and the AVZ (46-49 S), named the Patagonian volcanic gap [Stern 2004]. To the

${ }^{*}$ Corresponding author: sebastian.garcia@segemar.gov.ar south, in Antartica and sub-Antarctic areas, two volcanic zones with frequent volcanic eruptions are recognised: Deception and Penguin Island associated with the South Shetland Islands, in the Mar de la Flota or Bransfield rift [Viramonte et al. 1974b; Ortiz Ramís et al. 1992; De Rosa et al. 1995; Aparicio et al. 1997]. Another volcanic arc with several active volcanoes is located in the Southern Antilles (South Sandwich Islands) and includes Curry on Zavodovski Island; Belinda volcano on Jorge Island; Sourabaya on Blanca Island; etc., which are associated with the subduction of the small Sandwich plate situated between the South American, Antarctic and Scotia plates [Baker 1990; LeMasurier et al. 1990; Leat et al. 2000; Canclini 2009].

In the Argentine continental area there are around 120 active volcanoes (i.e. with documented historical activity, since the arrival of the Spanish between 500 and 200 years ago, and/or geological evidence of activity during the Holocene) in this segment of the Andes. Twenty of these volcanoes are situated entirely in Argentina; 18 are located on the Chile-Argentina border, and are thus considered binational volcanoes. The remaining volcanoes are located entirely in Chilean territory. [Elissondo and Villegas 2011; Elissondo and Farías 2016, Figure 1].

Despite hosting few volcanoes within Argentine borders, large areas of Argentine territory and airspace are affected by volcanic ash from explosive eruptions of 


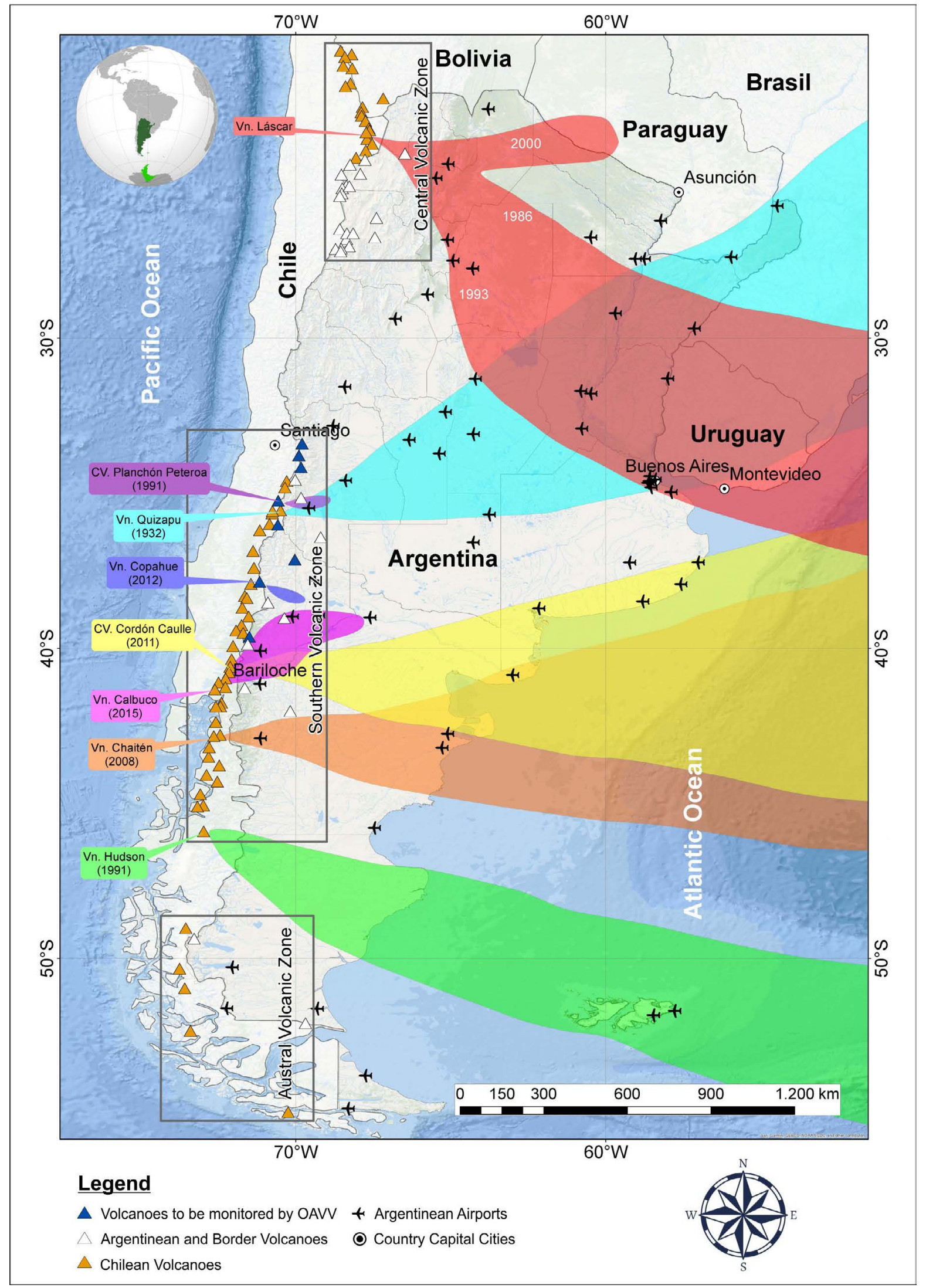

Figure 1: Map showing regions of ash dispersion from the most important historial eruptions that had an effect Argentine territory [modified from Viramonte et al. 2001]. 
Chilean volcanoes, owing to the dominantly westerly winds in the region [e.g. Scasso et al. 1994; Viramonte et al. 2001; Bonadonna et al. 2015]. Although ash dispersion and fallout do not usually generate direct loss of life, they can have important socio-economic and environmental effects [e.g. Elissondo et al. 2016].

Volcano-specific evaluations of volcano hazards in Argentina are incomplete. The occurrence and extent of hazardous phenomena in proximal and medial areas (with respect to the volcanic centre), such as pyroclastic flows, lahars and lava flows, have not been properly documented. This might be partially attributed to the relatively low population density close to volcanoes in Argentina. Nevertheless, the progressive increase of economic activity and investment in infrastructure (e.g. tourism, mining, gas and oil pipelines, new international border crossings, hydroelectric dams, among others) in the Andean region in recent decades is increasing exposure to these hazards.

Further, Antarctic and sub-Antarctic volcanism is very important for aeronavigation security, specifically due to transpolar flights. This area is principally under the surveillance of the Instituto Antártico Argentino, the Buenos Aires Volcanic Ash Advisor Center (VAAC Buenos Aires) and the Comision Nacional de Actividades Espaciales (CONAE).

Several important volcanic eruptions have affected Argentine territory over the last 88 years (e.g. Quizapu 1932, Decepcion Island 1967, 1969, 1970; Lascar 19861993; Hudson 1991; Chaitén 2008; Planchón-Peteroa 1991, 2011, 2018; Cordón Caulle 2011, Copahue 2012; Calbuco 2015). These eruptions not only affected thousands of people directly and produced millions of dollars in economic and material losses [Viramonte et al. 1974b; Hildreth and Drake 1992; Ortiz Ramís et al. 1992; De Rosa et al. 1995; Aparicio et al. 1997; Barbier 2011; Durant et al. 2012; Ministerio del Interior 2012; Collini et al. 2013; Osores et al. 2013; Elissondo et al. 2016; Reckziegel et al. 2016; Romero et al. 2016], but they also challenged local civil authorities and indirectly impacted populations across the country (Figure 1).

An iconic example of this is the explosive eruption of Puyehue-Cordón Caulle on June 4, 2011, which triggered the spontaneous evacuation of $\sim 4000$ inhabitants from Villa La Angostura, situated $50 \mathrm{~km}$ away to the south-east [Collini et al. 2013; Córdoba et al. 2015; Elissondo et al. 2016]. The ash cloud and associated ashfall also reached the cities of Villa Traful, San Carlos de Bariloche, and even Buenos Aires, forced local airports to close, and forced airlines to cancel local and international flights, generating huge economic losses. Road traffic was also affected at multiple scales by tephra fallout, even resulting in the closure of the International Pass Cardenal Samoré border crossing (to Chile) for almost three months. Other impacts associated with tephra accumulation included: collapse of dozens of poorly constructed roofs, obstruction of ur- ban drainage systems, contamination of water supplies, and interruption of electric power [Wilson et al. 2013; Craig et al. 2016; Elissondo et al. 2016]. The impacts on agriculture, livestock, and ecosystems were also severe: burying agricultural lands, causing a shortage of water and forage for the animals and resulting in the loss of animals, low birth rates and high predation. Almost ten years later, communities and ecosystems affected by this eruption are still in recovery [Wilson et al. 2013; Craig et al. 2016; Forte et al. 2018; Dominguez et al. 2020].

This article details the evolution of national volcanic risk management activities carried out by the Servicio Geológico Minero Argentino (SEGEMAR) since the 1990s in continental Argentine territory. This evolution is marked by some of the historic volcanic eruptions previously described. Currently, volcanic risk management at SEGEMAR is part of the Volcanic Threat Assessment Program, which consists of two main branches: The Volcanic Hazard and Geology Group and the Observatorio Argentino de Vigilancia Volcánica (OAVV).

\section{Volcanic risk assessment in Argentina}

\subsection{History of volcanic risk management in Argentina}

Volcano research in Argentina was carried out historically by different groups including universities and the Consejo Nacional de Investigaciones Científicas y Técnicas (CONICET) of Argentina (Table 1).

The eruptive crises in 1991 due to the eruptions of Hudson and, to a lesser extent, of Planchón-Peteroa volcanoes, showed civil authorities in Argentina the enormous damage that ashfall can cause. They also demonstrated the limited geological knowledge and Argentina's low institutional degree of preparation for volcanic threats. In response to this, SEGEMAR, with the support of the United Nations Development Program (UNDP) and the Servicio Nacional de Geología y Minería of Chile (SERNAGEOMIN), developed its first synoptic program to study the volcanic hazards presented by Argentine volcanoes [Haller et al. 1991; 1994]. The first result of this effort was the first binational geological and volcanic hazard map of PlanchónPeteroa volcano [Naranjo et al. 1999]. Over the following years, specific projects were carried out at other active volcanoes, such as Copahue [Sruoga and Consoli 2011], Maipo [Sruoga et al. 2012], Lanín and Laguna del Maule Volcanic Complex [Fierstein et al. 2013; Sruoga et al. 2015] in order to reconstruct their Holocene eruptive stratigraphy and assess their volcanic hazards. 
Table 1: Some of the research groups, centres, or university institutes or mixed dependency (University and Consejo Nacional de Investigaciones Científicas, CONICET) that have historically carried out volcano monitoring and volcanological research.

\begin{tabular}{|c|c|c|}
\hline Department, Center, or Institute & Institution or University & \\
\hline $\begin{array}{l}\text { Grupo de Estudio y Seguimiento de Vol- } \\
\text { canes Activos (GESVA) }\end{array}$ & Universidad de Buenos Aires (UBA) & CONICET \\
\hline Centro Nacional Patagónico (CENPAT) & Universidad Nacional del Comahue (UNCOMA) & CONICET \\
\hline $\begin{array}{l}\text { Instituto Andino Patagónico de Tecnologías } \\
\text { Biológicas y Geoambientales (IPATEC) }\end{array}$ & Universidad Nacional del Comahue (UNCOMA) & CONICET \\
\hline $\begin{array}{l}\text { Centro de Investigaciones en Ciencias de la } \\
\text { Tierra (CICTERRA) }\end{array}$ & Universidad Nacional de Cordoba (UNC) & CONICET \\
\hline $\begin{array}{l}\text { Instituto de Capacitación Especial y Desar- } \\
\text { rollo de Ingeniería Asistida por Computa- } \\
\text { dora (CEDIAC) }\end{array}$ & Universidad Nacional de Cuyo (UNCuyo) & CONICET \\
\hline $\begin{array}{l}\text { Instituto de Ecorregiones Andinas (IN- } \\
\text { ECOA) }\end{array}$ & Universidad Nacional de Jujuy (UNJu) & CONICET \\
\hline $\begin{array}{l}\text { Grupo de Sismología Volcánica, Facultad de } \\
\text { Ciencias Astronómicas y Geofísicas (FCAG) }\end{array}$ & Universidad Nacional de La Plata (UNLP) & \\
\hline $\begin{array}{l}\text { Centro de Investigaciones Geológicas (CIG), } \\
\text { Facultad de Ciencias Naturales y Museo (FC- } \\
\text { NyM) }\end{array}$ & Universidad Nacional de La Plata (UNLP) & CONICET \\
\hline $\begin{array}{l}\text { Instituto de Investigación en Paleobiología y } \\
\text { Geología (IIPG) }\end{array}$ & Universidad Nacional de Rio Negro (UNRN) & CONICET \\
\hline $\begin{array}{l}\text { Instituto Geonorte - Instituto de Bio y Geo- } \\
\text { ciencias del Noroeste Argentino (IBIGEO) }\end{array}$ & Universidad Nacional de Salta (UNSA) & CONICET \\
\hline $\begin{array}{l}\text { Facultad de Ciencias Naturales e Instituto } \\
\text { Miguel Lillo }\end{array}$ & Universidad Nacional de Tucumán (UNT) & CONICET \\
\hline
\end{tabular}

\subsection{Relative risk (threat) ranking for Argentina}

After the 2008 reawakening of Llaima and Chaitén volcanoes in Chile, SEGEMAR implemented its Volcanic Threat Assessment Program with the objective of assessing the possible environmental and socio-economic impacts associated with volcanic hazards/threats to the country. A rapid evaluation of the volcanic risk at the national continental level was carried out by Elissondo and Villegas [2011] and Elissondo and Farías [2016], allowing us to identify the volcanoes that present the highest risk and to organize future research projects and volcanic monitoring activities. This evaluation has laid the foundation on which strategic programs related to volcanic risk management in Argentina are being developed. The methodology was based on the Relative Threat Assessment System applied for the National Volcano Early Warning System (NVEWS), developed by the United States Geological Survey (USGS; [Ewert et al. 2005; Ewert 2007]), and also applied in other countries, including Chile [Lara et al. 2006], New Zealand [Miller 2011], and Peru [Macedo Sánchez et al.
2016], among others. In this approach, relative threat refers to the qualitative risk that a volcano poses to people and property. A numerical ranking is obtained through the analysis of different exposure and hazard factors for each volcano. The threat value is defined by the product of these two scores [Ewert et al. 2005; Ewert 2007]. The assessment was carried out for 38 volcanoes located in Argentine continental territory and on its international border (Table 2). Following the NVEWS methodology, several hazard and exposure factors were analyzed. The hazard assessment included analysis of 15 factors: the type of volcano, the frequency and magnitude of the eruptions, the eruptive products emitted in the Holocene, and the historical records of unrest. The sources of information were the Smithsonian Global Volcanism Program database, SEGEMAR geological maps and numerous scientific publications [Elissondo and Farías 2016]. The exposure was calculated on the analysis of 10 factors including the population living within $30 \mathrm{~km}$ of the volcano, the occurrence of fatalities or evacuations during historical eruptions or unrest, local and regional aviation expo- 
sure and transportation infrastructure, energy and sensitive areas of economic development. This information was obtained through the compilation of data from different institutions: Instituto Nacional de Estadística y Censos, Instituto Geográfico Nacional (IGN), Ministerio de Energía, Administración de Parques Nacionales, Organismo Regulador del Sistema Nacional de Aeropuertos, and Air Routes ICAO GIS Traffic Flow 2015 (International Civil Aviation Organization) [Elissondo and Farías 2016]. The results of the evaluation allowed the classification of analyzed volcanoes into four categories of relative risk including two Very High Risk volcanoes, six High Risk volcanoes, nine Moderate Risk volcanoes, and 21 Low Risk volcanoes. although it should be taken into account that the level of scientific knowledge of very high-and high-risk volcanoes is much higher than that of lower-risk volcanoes (Table 2).

\subsection{OAVV: the youngest volcano observatory in Latin America}

After the 2011 Cordon Caulle eruption, an idea developed within SEGEMAR for the creation of a specialized facility and staff dedicated to monitoring the volcanoes that could affect Argentina. But it was not until the eruption of Copahue volcano on 22 December 2012 that development of the OAVV started. The goal was to create an institution capable of studying and monitoring the activity of the continental Argentine volcanoes, through the instrumentation of the volcanoes that pose the highest threat to the country.

To accompany the beginning of the OAVV project, on January 27 2013, during the summit of the Comunidad de Estados Latinoamericanos y Caribeños in Santiago de Chile, government represenatives from Chile and Argentina signed a binational agreement for the "control, monitoring, and management" of volcanic eruptions in the border region between the two countries. This agreement represents a milestone regarding volcano monitoring and volcanic risk management between both countries and has laid solid foundations for the cooperation between SEGEMAR and SERNAGEOMIN (see also Amigo [2021] in this volume).

The first step of the project was to decide which volcanoes needed to be monitored. This decision was guided by the results of the Relative Risk Ranking (Threat). According to the ranking, a total of 15 volcanoes among the 38 Argentine volcanoes have very high to moderate risk (Table 2). Nevertheless, due to the large geographical extent of the active volcanic arc in the country and therefore the area to be monitored, the investment required for the installation and maintenance of stations has forced a strategy of deployment in stages. The first stage includes the eight most hazardous volcanoes of the SVZ, which have more frequent eruptions, and also are closer to bigger populations, infrastructure, and economic activities (Figure 2): Lanin, Copahue, Tromen, and Laguna del Maule volcanoes (Neuquén province) and Planchón-Peteroa, Maipo, Tupungatito, and San José volcanoes (Mendoza province; [García et al. 2017]). The second stage of the project will include the extension of monitoring networks to the very high to moderate risk volcanoes located in the CVZ.

The next step consisted of defining the desired level of ground-based instrumentation for each volcano, as well as the improvement in capacity building in satellite methodologies such as InSAR (interferometric synthetic aperture radar), thermal anomaly imaging, $\mathrm{SO}_{2}$ satellite anomalies, to monitor those volcanoes, which would not be instrumented. Decisions were made based on the criteria used by the USGS [Guffanti et al. 2010] alongside other experiences from different observatories in Latin America and adjusted to the available funding. This way, the eight selected highest priority volcanoes were divided into three categories according to their threat score from the volcanic risk assessment. Each category has different levels/amount of instrumentation based on their threat score.

For Category I volcanoes (Lanin, Copahue,PlanchónPeteroa, Maipo, Laguna del Maule) presenting the greatest threat, ground-based instrumentation was proposed to allow a very high level of monitoring, with the possibility of defining precursor patterns of eruptive activity in addition to conducting scientific studies so that complex volcanic processes can be modeled, as well as taking into consideration the need of redundancy. Volcanoes classified as Category II (Tupungatito, San José) have similar types of instrumentation as those of Category I, but with less dense coverage, so that precursor patterns can also be determined, but research will be limited to the general documentation of processes that occur at the volcano. Finally, Category III volcanoes (Tromen) will be instrumented to guarantee the minimum monitoring necessary to determine the base level of activity and confirm the onset of an eruption, but with little chance of detecting precursory changes.

The instrumentation proposed covers the increasingly standard suite of geophysical, geochemical, and visual techniques employed at observatories around the world: broadband seismometers, scanning-DOAS, GNSS stations, electronic tiltmeters, infrasound sensors and visual IP cameras. These stations will be selfsustaining using solar energy (solar panels and battery banks) and real time connection, through point to point/point-multipoint communication in the vicinity of each volcano, and a satellite communication system on the base of each volcano to relay data from the volcano to the headquarters of OAVV where the data storage, processing, and analysis center will be located. 
Table 2: Relative Risk Ranking (Threat) for continental Argentina developed by Elissondo et al. [2016]. Arg-Chile indicates volcanoes located within the region close to or on the international border.

\begin{tabular}{|c|c|c|c|c|c|c|}
\hline Ranking & Volcano Name & Location & $\begin{array}{c}\text { Province in } \\
\text { Argentina }\end{array}$ & Threat & Exposure & $\begin{array}{c}\text { Hazard } \\
\text { Index }\end{array}$ \\
\hline 1 & Copahue & Arg-Chile & Neuquén & 170.92 & 13.15 & 13 \\
\hline 2 & Planchón-Peteroa & Arg-Chile & Mendoza & 154.95 & 10.33 & 15 \\
\hline 3 & Laguna del Maule & Arg-Chile & Mendoza & 133.77 & 9.55 & 14 \\
\hline 4 & Tupungatito & Arg-Chile & Mendoza & 119.19 & 9.93 & 12 \\
\hline 5 & Lanín & Arg-Chile & Neuquén & 118.70 & 11.87 & 10 \\
\hline 6 & Maipo & Arg-Chile & Mendoza & 116.00 & 11.60 & 10 \\
\hline 7 & San José & Arg-Chile & Mendoza & 85.54 & 8.55 & 10 \\
\hline 8 & CV Cerro Blanco & Argentina & Catamarca & 84.21 & 8.42 & 10 \\
\hline 9 & Lastarria & Arg-Chile & Catamarca & 65.78 & 6.58 & 10 \\
\hline 10 & Viedma & Argentina & Neuquén & 64.26 & 10.71 & 6 \\
\hline 11 & Tuzgle & Argentina & Jujuy & 62.96 & 12.59 & 5 \\
\hline 12 & Tromen & Argentina & Neuquén & 62.07 & 12.41 & 5 \\
\hline 13 & Socompa & Arg-Chile & Salta & 56.38 & 8.05 & 7 \\
\hline 14 & Ojos del Salado & Arg-Chile & Catamarca & 51.64 & 5.74 & 9 \\
\hline 15 & Overo & Argentina & Mendoza & 48.16 & 9.63 & 5 \\
\hline 16 & Llullaillaco & Arg-Chile & Salta & 35.82 & 5.97 & 6 \\
\hline 17 & Aracar & Argentina & Salta & 28.35 & 7.09 & 4 \\
\hline 18 & CV Palei-Aike & Arg-Chile & Santa Cruz & 15.15 & 5.05 & 3 \\
\hline 19 & G Huanquihue & Argentina & Neuquén & 13.77 & 6.89 & 2 \\
\hline 20 & Tipas & Argentina & Catamarca & 13.76 & 6.88 & 2 \\
\hline 21 & Cordón del Azufre & Arg-Chile & Catamarca & 11.48 & 5.74 & 2 \\
\hline 22 & Cerro Bayo & Arg-Chile & Catamarca & 11.46 & 5.73 & 2 \\
\hline 23 & Infiernillo & Argentina & Mendoza & 11.39 & 5.70 & 2 \\
\hline 24 & Payún Matrú & Argentina & Mendoza & 8.51 & 4.26 & 2 \\
\hline 25 & Cerro Volcánico & Argentina & Rio Negro & 8.51 & 8.51 & 1 \\
\hline 26 & Laguna Blanca & Argentina & Neuquén & 8.31 & 8.31 & 1 \\
\hline 27 & Nevado de Incahuasi & Arg-Chile & Catamarca & 8.22 & 8.22 & 1 \\
\hline 28 & Cerro Escorial & Arg-Chile & Salta & 7.55 & 7.55 & 1 \\
\hline 29 & Peinado & Argentina & Catamarca & 6.45 & 6.45 & 1 \\
\hline 30 & Cerro El Cóndor & Argentina & Catamarca & 5.89 & 5.89 & 1 \\
\hline 31 & Sierra Nevada & Arg-Chile & Catamarca & 5.74 & 5.74 & 1 \\
\hline 32 & Falso Azufre & Arg-Chile & Catamarca & 5.72 & 5.72 & 1 \\
\hline 33 & El Solo & Argentina & Catamarca & 5.68 & 5.68 & 1 \\
\hline 34 & CV Antofagasta & Argentina & Catamarca & 4.91 & 4.91 & 1 \\
\hline 35 & Cerro Negro (Crater Basalt) & Argentina & Chubut & 4.37 & 4.37 & 1 \\
\hline 36 & Tralihue & Argentina & Neuquén & 3.85 & 3.85 & 1 \\
\hline 37 & Salar de Arizaro & Argentina & Salta & 2.30 & 2.30 & 1 \\
\hline 38 & Sin Nombre & Argentina & Salta & 1.60 & 1.60 & 1 \\
\hline
\end{tabular}

\section{HOW DO WE MONITOR THESE VOLCANOES?}

\subsection{History of volcano monitoring in Argentina}

Since the beginning of the $21^{\text {st }}$ century, prior to creation of the OAVV, the study and monitoring of volcanic activity in Argentina using modern techniques was carried out by university geology and geophysics departments and research groups (Table 1) in collaboration with international scientific groups mainly from Italy and Spain, among other countries [e.g. Ibáñez et al. 2008; Agusto et al. 2013; Casas et al. 2014; Tassi et al. 2016].
Some of the early application of volcano monitoring techniques in Argentina was on Deception Island in Antarctica [Viramonte et al. 1974a; b; Ortiz Ramís et al. 1987; Ramos et al. 1990; Ortiz Ramís et al. 1992; Risso and Ortiz Ramís 1994; De Rosa et al. 1995; Aparicio et al. 1997; Caselli and Agusto 2004; Bonatto et al. 2007; Caselli et al. 2007] and then at Copahue Volcano [Ibáñez et al. 2008; Agusto et al. 2012]. Other limited monitoring programs took place at other volcanoes including Cerro Blanco [Lopez et al. 2014] and PlanchónPeteroa [Casas et al. 2014].

The primary objectives of these early efforts were research into volcanic processes, without an emphasis on 


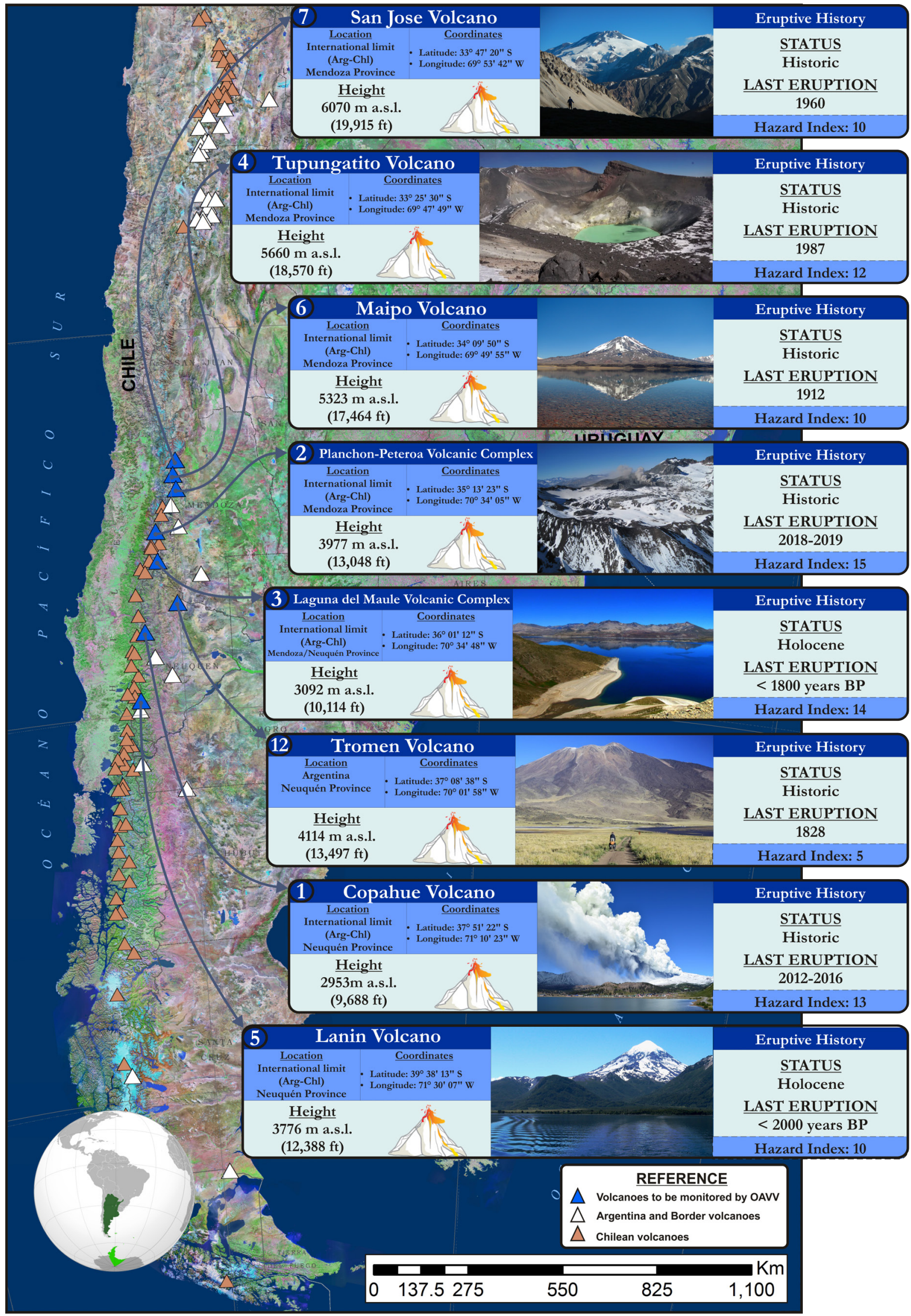

Figure 2: Regional location map of the volcanoes of the Andes; blue triangles indicate volcanoes that are monitored (or will be monitored in the future) [modified from García et al. 2017]. 
continuous monitoring in real time to support early warning systems.

\subsection{Current monitoring activities and capacities}

The OAVV project finally materialized in 2017 with the acquisition of initial equipment and the hiring of professionals that form the present staff of the observatory. The location of the future OAVV headquarters and the development of the headquarters construction project is yet to be defined. In the meantime, OAVV staff are working from the central headquarters of SEGEMAR, in Buenos Aires. Currently, OAVV monitors the two most active volcanoes in Argentina in real time: Copahue and Planchón-Peteroa, in cooperation with the Observatorio Volcanológico de los Andes del Sur (OVDAS) in Chile (Figure 3). This work is carried out by an interdisciplinary working group composed of five professionals, which includes geologists, geochemists and geophysicists. Also, the OAVV staff collaborates with three geologists from the Volcanic Hazard Group of SEGEMAR and four professionals from the GIS and Remote Sensing Area (thermal imaging processing and radar interferometry techniques: InSAR).



Figure 3: Binational volcano monitoring network for Copahue volcano.

The real-time monitoring network at PlanchónPeteroa volcano consists of two seismic stations and two IP cameras on the Argentine side of the volcano. This is complemented by remote sensing and the analysis of multiple types of satellite images. Advanced Spaceborne Thermal Emission and Reflection Radiometer (ASTER) images are used to track temperature changes in the crater, NASA Firms Visible Infrared Imaging Radiometer Suite (VIIRS), $375 \mathrm{~m}$ near real time (NRT), and Suomi National Polar-orbiting Partnership (Suomi NPP) for performing thermal anomaly alerts, and radar images for mapping ground deformation (i.e. InSAR). Also, water and gas geochemistry sampling campaigns are regularly carried out in summer. Gas and water samples are jointly collected with Grupo de Estudio y Seguimiento de Volcanes Activos from the Universidad de Buenos Aires (GESVA-UBA) while direct gas sampling $\left(\mathrm{SO}_{2}, \mathrm{CO}_{2}\right.$ and $\left.\mathrm{H}_{2} \mathrm{~S}\right)$ of fumaroles with a MultiGAS instrument is performed in collaboration with professionals from Internacional Center for Earth Science (ICES) from the Comisión Nacional de Energía Atómica (CNEA).

Monitoring of Copahue volcano is possible through the binational agreements signed between SEGEMAR and SERNAGEOMIN, permitting exchange of information in realtime between OAVV and OVDAS. This allows the staff of OAVV to receive and process information from six seismic stations and two IP cameras (Figure 3). Monitoring is complemented by the same remote sensing techniques applied in Planchón-Peteroa, and the summer geochemistry sampling campaigns.

\section{VOLCANO HAZARD MANAGEMENT}

To date, there are only two completed volcanic hazard maps for Argentine volcanoes-Copahue [Bermúdez and Delpino 1995] and Planchón-Peteroa [Naranjo et al. 1999] —and it has been determined that they require updating according to new information (such as newly published geological and volcanological research) and methodologies. For that reason, and in the framework of SEGEMAR's Volcanic Threat Assessment Program, the Volcanic Hazard Group from the Dirección de Geología Ambiental y Aplicada of SEGEMAR has been, since 2016, developing volcanic hazard maps for the top priority volcanoes (prioritized according to relative risk ranking). Using the Relative Risk Ranking for Argentina [Elissondo and Farías 2016] as a baseline, SEGEMAR launched the Volcanic Hazard Map Program, starting with the maps from Laguna del Maule Volcanic Complex [Gho et al. 2019] and Lanín and Copahue volcanoes. The first two maps were carried out within the frame of the binational agreement between SEGEMAR and SERNAGEOMIN (with the assistance of the USGS' Volcano Disaster Assistance Program ).

The hazard evaluation requires a detailed geologicalgeomorphological study of each volcano, coupled with information regarding topography, hydrology, meteorological data, and historical reports of activity, among other data. The hazard mapping activities include field surveys, geological mapping and sampling with the main goal of reconstructing the postglacial eruptive history of the studied volcano and identifying the different volcanic products and associated hazards. The identified products are then characterized (e.g. volume, length, etc.) to give information about eruption characteristics and parameters. After reconstructing the postglacial eruptive history, most probable eruption scenar- 
ios are defined which, depending on the information available, may be probabilistic or deterministic. For the different scenarios and for each volcanic hazard, susceptibility maps are prepared. These maps depict areas likely to be affected by each volcanic hazard for the different eruptive scenarios defined, and they are obtained using different modelling techniques. The hazard zonation is obtained by assigning probabilities of occurrence to the susceptible areas, according to previously performed probabilistic analysis [Calder et al. 2015]. The maps created by SEGEMAR are semi-quantitative and multi-hazard. The analysis and results are presented at different scales: the proximal hazards are shown on a detailed scale, in general 1:50000 (e.g. pyroclastic density currents, lava flows, lahars, ballistics, proximal tephra fallout), while tephra fallout with a regional distribution is presented at a scale smaller than 1:2000000.

SEGEMAR carries out research and monitoring of volcanic activity within the framework of the new Sistema Nacional para la Gestión Integral del Riesgo (SINAGIR), created in 2016 through the enactment of Law $\mathrm{N}^{\circ} 27287$. This law aims to integrate the actions and articulate the operation of the national, provincial and municipal government agencies, non-governmental organizations and the civil society, to strengthen and optimize actions focused on risk reduction, crisis management and recovery. Within this framework, SEGEMAR is part of the Red de organismos científico técnicos para la gestión del riesgo de desastres (Red GIRCYT) and coordinates the volcanic hazard segment of the Plan Nacional de Reducción de Riesgo de Desastres (PNRRD 2018-2023). The PNRRD seeks to define the political guidelines and basic principles that should be developed by public and private institutions, as well as social organizations, for the execution of programs and actions aimed at reducing existing risks, guarantee better security conditions for citizens, and protect economic, social, environmental and cultural heritage. Also, SEGEMAR has been responsible for the coordination and implementation of the Interinstitutional Protocol for Information Management in the face of a volcanic activity threat that may affect Argentine territory. This protocol aims to articulate the access to information and data generated by technical and scientific agencies that are part of the GIRCYT Network, with the purpose of generating data and scientific products, and making them available to stakeholders and decision makers in order to manage volcanic risk. Since Argentina is a federal country, preparedness and response stages are managed by the local and provincial civil defenses, who are responsible for helping communities prepare for eruptions, and eventually manage evacuation process in case of an event. Nevertheless, volcanic risk awareness in Argentina is very low, and due to this, most provinces do not yet have response plans to deal with them, with the exception of particular cases, like the province of Neuquén, which recently dealt with significant eruptions (i.e. Cordón
Caulle 2011, Copahue 2012, Calbuco 2015) and developed emergency plans to deal with volcanic risks. SEGEMAR through the OAVV has been raising volcanic risk awareness in the country, as well as proposing in collaboration with other national organizations the implementation of national policies through the PNRRD (2018-2023), to raise awareness of these risks at a national level.

\section{INFORMATION DISSEMINATION AND OUT- REACH}

The OAVV is responsible for issuing Volcanic Alert Levels (or "technical alerts") to the national, provincial and municipal authorities as well as to the civil population, through the National Platform of Alerts and Monitoring of SINAGIR. OAVV periodically sends Volcanic Activity Reports (RAV) and Special Volcanic Activity Reports (REAV) of Argentine and Chilean volcanoes using a mailing list, the SEGEMAR website and social networks. In this context, SEGEMAR has recently launched a new dedicated section on its website (https://oavv. segemar.gob.ar) to improve public access to information related to monitored Argentine volcanoes. This information includes basic information on volcanic hazard processes, information about SEGEMAR's volcano monitoring networks, and reports on the status of Argentine and Chilean volcanoes.

One of the main foundational pillars of the OAVV, as a new specialized center at the national level, is the consolidation of national and international collaboration networks of scientists who are involved in volcanic studies and emergency response. Currently, OAVV collaborates at a national level with other scientific and technical organizations of the national government including: the Servicio Meteorológico Nacional Argentino, where the VAAC operates; the IGN, who is in charge of the national cartography of the country as well as the management of the national geodetic network; the CONAE, which guarantees access to satellite images for volcano monitoring applying remote sensing techniques; ICES-CNEA and the Instituto de Investigaciones Científicas y Técnicas para la Defensa. The OAVV also collaborates with several groups of researchers from national universities such as: GESVA-UBA; the Volcano Seismology Group at FCAG-UNLP; the Satellite Images group of the CEDIAC Institute from the UNCuyo; the IIPG at the UNRN; Geonorte Institute and IBIGEO at UNSA and the UNCOMA (See Table 1 for meaning of acronyms).

On the international side, SEGEMAR has a formal institutional policy to develop strong bonds with other geological surveys with extensive experience in volcanology and volcano monitoring. That is why, initially, multiple binational agreements where signed with Chile. Also, SEGEMAR has signed agreements with the USGS and the Servicio Geológico Colombiano 
for the transfer of knowledge and technology, and the training of OAVV professionals, in order to replicate the best practices implemented in both countries. This will lay the foundation for effective operations, sustained and strategic growth, and generation and recruitment of specialized human resources and the development of scientific research projects that can complement volcano monitoring activities.

\section{NeEds, Challenges, AND future PERSPEC- TIVES}

OAVV is the first permanent volcano observatory in Argentina and the youngest in Latin America. Its success will produce a stable foundation for modern volcano surveillance, early warning systems, and volcanology research in Argentina.

The main goal for the future is to maintain an effective volcanic monitoring system that can improve volcanic risk management in Argentina. As part of this, OAVV will strive to generate accurate and updated information on the activity of the volcanoes that may affect Argentine territory, and make this information available to stakeholders and authorities at different political levels as well as to civilian population. The main challenge is to obtain the resources to reach this goal before a volcanic eruption that severely impacts lives, infrastructure, and regional economies. Likewise, the generation of instrumental monitoring networks and the application of advanced monitoring methodologies used worldwide will allow the training of new professionals in the country together with different university and CONICET volcanological research centers, helping to build a new generation of Argentine volcanologists.

\section{Acknowledgements}

We would like to thank the authorities of SEGEMAR for allowing the development of this work and the reviewers for the comments and suggestions, which have improved the clarity and completeness of the manuscript. We would like to especially thank M. Elissondo for providing most of the information on the volcanic Hazard Assessment and the Relative Risk Ranking.

\section{Author contributions}

S. Garcia was responsible for the development and execution of this manuscript. G. Badi was responsible for the revision and internal review of the document.

\section{Data aVailability}

Data available on request. The reports issued by the OAVV are publicly available on the website (https:// oavv.segemar.gob.ar/). The information related to the hazard assessment and the future volcanic hazard maps to be published are openly available in the SEGEMAR public repository (https://repositorio.segemar.gov. $\operatorname{ar} /)$.

\section{COPYRIGHT NOTICE}

(C) The Author(s) 2021. This article is distributed under the terms of the Creative Commons Attribution 4.0 International License, which permits unrestricted use, distribution, and reproduction in any medium, provided you give appropriate credit to the original author(s) and the source, provide a link to the Creative Commons license, and indicate if changes were made.

\section{REFERENCES}

Agusto, M., F. Tassi, A. Caselli, O. Vaselli, D. Rouwet, B. Capaccioni, S. Caliro, G. Chiodini, and T. Darrah (2013). "Gas geochemistry of the magmatic-hydrothermal fluid reservoir in the Copahue-Caviahue Volcanic Complex (Argentina)". Journal of Volcanology and Geothermal Research 257, pp. 44-56. Dor: 10.1016/j . jvolgeores. 2013.03.003.

Agusto, M., A. Caselli, F. Tassi, M. Dos Santos Afonso, and O. Vaselli (2012). "Seguimiento geoquímico de las aguas ácidas del sistema volcán Copahue-Río Agrio: posible aplicación para la identificación de precursores eruptivos". Revista de la Asociación Geológica Argentina 69 (4), pp. 481-495.

Allmendinger, R. W., T. E. Jordan, S. M. Kay, and B. L. Isacks (1997). "The evolution of the Altiplano-Puna plateau of the Central Andes". Annual Review of Earth and Planetary Sciences 25 (1), pp. 139-174. DoI: 10.1146/annurev. earth.25.1.139.

Amigo, Á. (2021). "Volcano monitoring and hazard assessments in Chile". Volcanica 4 (S1), pp. 1-20. Dor: 10.30909/vol.04.S1.0120.

Aparicio, A., C. Risso, J. G. Viramonte, M. Menegatti, and I. A. Petrinovic (1997). "El volcanismo de Isla Decepción (Península Antártica)”. Boletín geológico y minero 108 (3), pp. 235-258.

Baker, P. E. (1990). "South Sandwich Islands". Volcanoes of the Antarctic Plate and Southern Oceans. Ed. by W. LeMasurier, J. Thomson, P. Baker, P. Kyle, P. Rowley, J. Smellie, and W. Verwoerd. Vol. 48. American Geophysical Union, pp. 361-395. Dor: 10.1029/ar048.

Barazangi, M. and B. L. Isacks (1976). "Spatial distribution of earthquakes and subduction of the Nazca plate beneath South America". Geology 4 (11), p. 686. DOI: $10.1130 / 0091-7613(1976) 4<686$ : sdoeas $>2$. $\odot$. $\mathrm{co} ; 2$.

Barbier, J. L. (2011). “Erupción del Volcán PuyehueCordón Caulle en la República de Chile, 4 de junio del 2011". Seminario Regional "Alianzas entre el sector público y privado para la gestión del riesgo 
de desastres: Continuidad de gobierno y continuidad de operaciones ante situaciones de desastres". Lima, SP/SRCGCORRD/Di.

Bermúdez, A. and D. Delpino (1995). Mapa de los peligros potenciales en el área del Volcán Copahue-sector Argentino.

Bonadonna, C., R. Cioni, M. Pistolesi, M. Elissondo, and V. Baumann (2015). "Sedimentation of long-lasting wind-affected volcanic plumes: the example of the 2011 rhyolitic Cordón Caulle eruption, Chile". Bulletin of Volcanology 77 (2). DOI: 10.1007/s00445-0150900-8.

Bonatto, A. L., G. A. Badi, A. Bidone, A. Caselli, C. L. Bengoa, and J. M. Ibañez (2007). "Isla Decepción: actividad sismovolcánica y localización de fuentes para los veranos 2003-2004 y 2004-2005”. Actas del VI Simposio Argentino y $I I I^{\circ}$ Latinoamericano sobre Investigaciones Antárticas. Buenos Aires, pp. 1-4.

Calder, E., K. Wagner, and S. Ogburn (2015). "Volcanic hazard maps". Global Volcanic Hazards and Risk. Ed. by S. C. Loughlin, S. Sparks, S. K. Brown, S. F. Jenkins, and C. Vye-Brown. Cambridge University Press, pp. 335-342. Dor: 10.1017/cbo9781316276273.022.

Canclini, A. (2009). Islas Sandwich del Sur: la Argentina en el Atlántico Sur. Buenos Aires, Argentina: Zagier \& Urruty Publications. IsBN: 978-987-1468-10-2.

Casas, J. A., G. A. Badi, M. C. Manassero, E. Ruigrrok, M. Gomez, D. Draganov, and J. Ruzzante (2014). "Characterization of Seismo-volcanic Activity in Peteroa Volcano, Central Chile-Argentina”. Proceedings. First Assembly of the Latin-America and Caribbean Seismological Commission - LACSC. Vol. 18, pp. 335-336.

Caselli, A. T. and M. R. Agusto (2004). "Depósitos hidrovolcánicos recientes con indicios de inmiscibilidad magmática en la isla Decepción (Antártida)". Revista de la Asociación Geológica Argentina 59 (3), pp. 495-500.

Caselli, A. T., G. Badi, A. Bonatto, C. Bengoa, M. Agusto, A. Bidone, and J. Ibáñez (2007). "Actividad sísmica y composición química fumarólica anómala debido a posible efecto sello en el sistema volcánico, Isla Decepción (Antártida)". Revista de la Asociación Geológica Argentina 62 (4), pp. 545-552.

Coira, B., S. M. Kay, and J. Viramonte (1993). "Upper Cenozoic magmatic evolution of the Argentine Puna-A model for changing subduction geometry". International Geology Review 35 (8), pp. 677-720. DoI: 10. 1080/00206819309465552.

Collini, E., M. S. Osores, A. Folch, J. G. Viramonte, G. Villarosa, and G. Salmuni (2013). "Volcanic ash forecast during the June 2011 Cordón Caulle eruption". Natural Hazards 66 (2), pp. 389-412. ISsN: 1573-0840. DoI: $10.1007 / \mathrm{s} 11069-012-0492-y$.

Córdoba, G., G. Villarosa, M. F. Sheridan, J. G. Viramonte, D. Beigt, and G. Salmuni (2015). "Secondary lahar hazard assessment for Villa la Angostura, Argentina, using Two-Phase-Titan modelling code during 2011 Cordón Caulle eruption". Natural Hazards and Earth System Sciences 15 (4), pp. 757-766. Dor: 10.5194/nhess-15-757-2015.

Craig, H., T. Wilson, C. Stewart, V. Outes, G. Villarosa, and P. Baxter (2016). "Impacts to agriculture and critical infrastructure in Argentina after ashfall from the 2011 eruption of the Cordón Caulle volcanic complex: an assessment of published damage and function thresholds". Journal of Applied Volcanology 5 (1). ISSN: 2191-5040. DOI: 10.1186/s13617-016-0046-1.

Davidson, J. P. and S. L. de Silva (1995). "Late Cenozoic magmatism of the Bolivian Altiplano". Contributions to Mineralogy and Petrology 119 (4), pp. 387-408. Dor: $10.1007 / \mathrm{bf00286937.}$

De Rosa, R., R. Mazzuoli, R. H. Omarini, G. Ventura, and J. G. Viramonte (1995). "A volcanological model for the historical eruptions at Deception Island (Bransfield Strait, Antarctica)". Terra Antartica 2 (2), pp. 95-101.

Dominguez, L., C. Bonadonna, P. Forte, P. A. Jarvis, R. Cioni, L. Mingari, D. Bran, and J. E. Panebianco (2020). "Aeolian Remobilisation of the 2011-Cordón Caulle Tephra-Fallout Deposit: Example of an Important Process in the Life Cycle of Volcanic Ash". Frontiers in Earth Science 7. IssN: 2296-6463. Dor: 10.3389/ feart. 2019.00343.

Durant, A. J., G. Villarosa, W. I. Rose, P. Delmelle, A. J. Prata, and J. G. Viramonte (2012). "Long-range volcanic ash transport and fallout during the 2008 eruption of Chaitén volcano, Chile". Physics and Chemistry of the Earth, Parts $A / B / C$ 45-46, pp. 50-64. DoI: 10.1016/j.pce.2011.09.004.

Elissondo, M., V. Baumann, C. Bonadonna, M. Pistolesi, R. Cioni, A. Bertagnini, S. Biass, J.-C. Herrero, and R. Gonzalez (2016). "Chronology and impact of the 2011 Cordón Caulle eruption, Chile”. Natural Hazards and Earth System Sciences 16 (3), pp. 675-704. DoI: $10.5194 /$ nhess-16-675-2016.

Elissondo, M. and C. Farías (2016). "Volcanic risk assessment in Argentina". Cities on Volcanoes 9: Understanding Volcanoes and Society - The Key for Risk Mitigation. Puerto Varas.

Elissondo, M. and D. Villegas (2011). "Evaluación de peligrosidad volcánica en Argentina”. Geología y Recursos Naturales de la provincia del Neuquén: Relatorio XVIII Congreso Geológico Argentino. Ed. by H. Leanza, C. Arregui, O. Carbone, D. J., and J. Vallés. Vol. 2, pp. 609-616.

Ewert, J. W. (2007). "System for Ranking Relative Threats of U.S. Volcanoes". Natural Hazards Review 8 (4), pp. 112-124. DOI: 10.1061 / (ASCE ) 1527 6988(2007) 8:4(112).

Ewert, J. W., M. Guffanti, and T. L. Murray (2005). An assessment of volcanic threat and monitoring capabilities in the United States: framework for a National Volcano Early Warning System. Tech. rep. US Geological Survey. DoI: 10.3133/ofr20051164.

Fierstein, J., P. Sruoga, A. Amigo, M. Elissondo, and M. Rosas (2013). "Tephra in Argentina establishes post- 
glacial eruptive history of Laguna del Maule volcanic field in Chile". IAVCEI Scientific Assembly - 2013: Forecasting Volcanic Activity: reading and translating the messages of nature for society. Kagoshima, pp. 2317.

Forte, P., L. Domínguez, C. Bonadonna, M. Lamberti, C. E. Gregg, D. Bran, and J. M. Castro (2018). "Tormentas de ceniza volcánica en Patagonia: un peligro latente y subestimado". Libro de resúmenes: VIII Foro Internacional los Volcanes y su impacto, Arequipa, 26 y 27 de abril del 2018. Ed. by R. Aguilar. Arequipa, pp. 137-141.

García, S., G. Badi, and A. Tejedo (2017). "Proyecto Observatorio Argentino de Vigilancia Volcánica (OAVV) del Servicio Geológico Minero Argentino". XX Congreso Geológico Argentino, Actas. Tucumán.

Gho, R., P. Sruoga, Á. Amigo, J. Fierstein, M. Elissondo, J. Kaufman, V. Toloza, and R. Calderón (2019). Peligros del Complejo Volcánico Laguna del Maule, región del Maule, Chile - Provincias de Mendoza y Neuquén, Argentina. Tech. rep. [Mapa escala 1: 75,000].

Guffanti, M., A. K. Diefenbach, J. W. Ewert, D. W. Ramsey, P. F. Cervelli, and S. P. Schilling (2010). Volcanomonitoring instrumentation in the United States, 2008. Tech. rep. US Geological Survey.

Haller, M. J., J. E. Mendía, and H. A. Ostera (1991). "Mapa preliminar de riesgo en la vertiente Argentina del volcán Peteroa". $6^{\circ}$ Congreso Geológico Chileno. Santiago: Servicio Nacional de Geología y Minería Chile, pp. 355-358.

Haller, M. J., H. A. Ostera, A. H. Pesce, M. Gardini, and A. Folgueras (1994). "Vulcanoestratigrafía reciente y eruptividad del volcán Peteroa". $7^{\circ}$ Congreso Geológico Chileno. Vol. 1. Universidad de Concepcion, pp. 319323.

Hildreth, W. and R. E. Drake (1992). "Volcán Quizapu, Chilean Andes". Bulletin of Volcanology 54 (2), pp. 93-125. DOI: 10.1007/bf00278002.

Ibáñez, J., E. Del Pezzo, C. Bengoa, A. Caselli, G. Badi, and J. Almendros (2008). "Volcanic tremor and local earthquakes at Copahue volcanic complex, Southern Andes, Argentina". Journal of Volcanology and Geothermal Research 174 (4), pp. 284-294. DOI: 10 . 1016/j . jvolgeores. 2008.02.005.

Isacks, B. L., S. M. Kay, E. J. Fielding, and T. Jordan (1986). "Andean volcanism: icing on the cake". Eos 67, p. 1073.

Jordan, T. E., B. L. Isacks, R. W. Allmendinger, J. A. Brewer, V. A. Ramos, and C. J. Ando (1983). "Andean tectonics related to geometry of subducted Nazca plate". Geological Society of America Bulletin 94 (3), p. 341. DOI: $10.1130 / 0016-7606(1983) 94<341$ : atrtgo $>2.0 . \operatorname{co} ; 2$.

Kay, S. M., B. Coira, and J. Viramonte (1994). "Young mafic back arc volcanic rocks as indicators of continental lithospheric delamination beneath the Argentine Puna Plateau, central Andes". Journal of Geo- physical Research: Solid Earth 99 (B12), pp. 2432324339. Dor: $10.1029 / 94$ jb00896.

Lara, L. E., J. Clavero, M. Hinojosa, S. Huerta, R. Wall, and H. Moreno (2006). "NVEWS-CHILE: Sistema de Clasificación semicuantitativa de la vulnerabilidad volcánica”. Congreso Geológico Chileno. Vol. 11. Antofagasta, pp. 487-490.

Leat, P. T., R. A. Livermore, I. L. Millar, and J. A. Pearce (2000). "Magma Supply in Back-arc Spreading Centre Segment E2, East Scotia Ridge". Journal of Petrology 41 (6), pp. 845-866. Dor: 10.1093/petrology/41. 6.845 .

LeMasurier, W., J. Thomson, P. Baker, P. Kyle, P. Rowley, J. Smellie, and W. Verwoerd, eds. (1990). Vol. 48. American Geophysical Union. Dor: 10.1029/ar048.

Lopez, F., J. G. Viramonte, M. Berrocoso, I. Barbero, P. Euillades, and M. Blanco (2014). "Validación de la Subsidencia del Complejo Volcánico Cerro Blanco con el uso de GPS Diferencial Geodésico”. XX Congreso Geológico Argentino, Actas. Córdoba: Asociación Geológica Argentina.

Macedo Sánchez, O. E., E. Taipe, J. A. Del Carpio Calienes, J. Ticona, D. A. Ramos Palomino, N. Puma Sacsi, V. Aguilar, R. Machacca, J. L. Torres Aguilar, J. E. Cueva Kevin aand Cruz Igme, I. Lazarte, R. Centeno Quico, R. Miranda, Y. Alvarez, P. Masias, J. Vilca, F. Apaza, R. Chijcheapaza, J. Calderón, J. Caceres, and J. Vela (2016). Evaluación del riesgo volcánico en el sur del Perú, situación de la vigilancia actual y requerimientos de monitoreo en el futuro. Tech. rep. Instituto Geológico, Minero y Metalúrgico (INGEMMET), Universidad Nacional de San Agustín (UNSA).

Miller, C. A. (2011). Threat assessment of New Zealand's volcanoes and their current and future monitoring requirements Lower Hutt, N.Z. Tech. rep. GNS Science.

Ministerio del Interior (2012). Consideraciones para una estrategia para la gestión integral del riesgo de desastres en Argentina. Nota Conceptual, Informe Inédito.

Naranjo, J. A., M. J. F. Haller, H. A. Ostera, A. H. Pesce, and P. Sruoga (1999). "Geología y Peligros del Complejo Volcánico Planchón-Peteroa, Andes del Sur (3515' S), Región del Maule, Chile-Provincia de Mendoza, Argentina”. Servicio Nacional de Geología y Minería Chile (52), pp. 1-56.

Ortiz Ramís, R., J. L. Díez Gil, and J. G. Viramonte (1987). "Modelo numérico para la simulación del transporte y deposición del piroclastos: aplicación al estudio de las erupciones de 1967, 1969 y 1970 ocurridas en Decepción (Antártida)". XXI Reunión bienal de la Real Sociedad española de Física. Real Sociedad Española de Física. Salamanca, pp. 347-348.

Ortiz Ramís, R., J. Vila, A. García, A. Camacho, J. L. Díez Gil, A. Aparicio, R. Soto, J. G. Viramonte, C. Risso, N. Menegatt, and I. Petrinovic (1992). "Geophysical features of Deception Island". Recent progress in Antarctic earth science. Ed. by Y. Yoshida, K. Kaminuma, and K. Shiraishi. Tokyo: Terra Scientific Publishing, pp. 443-448. 
Osores, M. S., A. Folch, E. Collini, G. Villarosa, A. Durant, G. Pujol, and J. G. Viramonte (2013). "Validation of the FALL3D model for the 2008 Chaitén eruption using field and satellite data". Andean Geology 40 (2). DoI: $10.5027 /$ andgeov40n2-a05.

Ramos, M., R. Ortiz Ramís, J. L. Díez Gil, and J. G. Viramonte (1990). "Anomalías térmicas y balance de flujo energético sobre el suelo del volcán Decepción, Isla Decepción (Shetland del Sur)". II Simposio Español de Investigaciones Antárticas. Gredos, pp. 203219.

Ramos, V. A., E. Cristallini, and D. J. Pérez (2002). "The Pampean flat-slab of the Central Andes". Journal of South American Earth Sciences 15 (1), pp. 59-78. DoI: 10.1016/s0895-9811(02)00006-8.

Reckziegel, F., E. Bustos, L. Mingari, W. Báez, G. Villarosa, A. Folch, E. Collini, J. Viramonte, J. Romero, and S. Osores (2016). "Forecasting volcanic ash dispersal and coeval resuspension during the April-May 2015 Calbuco eruption". Journal of Volcanology and Geothermal Research 321, pp. 44-57. DoI: $10.1016 /$ j . jvolgeores.2016.04.033.

Risso, C. and R. Ortiz Ramís (1994). Directory of volcano observatories (1993-1994). Paris: World Organization of Volcano Observatories; UNESCO.

Romero, J., D. Morgavi, F. Arzilli, R. Daga, A. Caselli, F. Reckziegel, J. Viramonte, J. Diaz-Alvarado, M. Polacci, M. Burton, and D. Perugini (2016). "Eruption dynamics of the 22-23 April 2015 Calbuco Volcano (Southern Chile): Analyses of tephra fall deposits". Journal of Volcanology and Geothermal Research 317, pp. 15-29. Dor: 10.1016/j . jvolgeores. 2016.02.027.

Scasso, R. A., H. Corbella, and P. Tiberi (1994). "Sedimentological analysis of the tephra from the 12-15 August 1991 eruption of Hudson volcano". Bulletin of Volcanology 56 (2), pp. 121-132. DOI: 10.1007 / bf 00304107 .

Sruoga, P. and V. Consoli (2011). "Volcán Copahue". Geología y Recursos Naturales de la provincia del Neuquén: Relatorio XVIII Congreso Geológico Argentino. Ed. by H. Leanza, C. Arregui, O. Carbone, D. J., and J. Vallés. Vol. 2, pp. 609-616.

Sruoga, P., M. Elissondo, J. Fierstein, S. García, R. González, and M. Rosas (2015). "Actividad explosive postglacial del centro Barrancas, Complejo Volcánico Laguna del Maule.(36 05'S, 70 30'O). Peligrosidad en Argentina". XIV congreso geológico chileno. Sociedad Geológica de Chile La Serena, Chile, pp. 4952 .
Sruoga, P., M. P. Etcheverría, M. Feineman, M. Rosas, C. Bukert, and O. D. Ibañes (2012). "Complejo Caldera Diamante-Volcán Maipo (34 10’ S, 69 50’ O): evolución volcanológica y geoquímica e implicancias en su peligrosidad". Revista de la Asociación Geológica Argentina 69 (4), pp. 508-530.

Stern, C. R. (2004). "Active Andean volcanism: its geologic and tectonic setting". Revista geológica de Chile 31 (2), pp. 161-206.

Stern, C. R. and R. Kilian (1996). "Role of the subducted slab, mantle wedge and continental crust in the generation of adakites from the Andean Austral Volcanic Zone". Contributions to Mineralogy and Petrology 123 (3), pp. 263-281. DoI: 10.1007/s004100050155.

Tassi, F., F. Aguilera, O. Benavente, A. Paonita, G. Chiodini, S. Caliro, M. Agusto, F. Gutierrez, B. Capaccioni, O. Vaselli, A. Caselli, and O. Saltori (2016). "Geochemistry of fluid discharges from Peteroa volcano (Argentina-Chile) in 2010-2015: Insights into compositional changes related to the fluid source region(s)". Chemical Geology 432, pp. 41-53. Dor: 10 . 1016/j. chemgeo. 2016.04.007.

Viramonte, J. G., G. E. Bossi, R. J. Sureda, N. H. Fourcade, and R. H. Omarini (1974a). "Geochemical and mineralogical study of the high temperature fumaroles from Deception Island, South Shetland, Antarctica". Proceedings of the Symposium on Andean and Antarctic Volcanology Problems, Santiago, Chile. Santiago, Chile: Instituto geografico militar, pp. 543561.

Viramonte, J. G., C. M. Peralta, D. Garrido, and A. Felpeto (2001). Uso De Sensores Remotos Para La Mitigacion De Efectos Causados Por Erupciones Volcanicas: Elaboración de mapas de Riesgo volcánico y alertas para la aeronavegación: Un caso de estudio. URL: http : // WWW . conae . gov . ar /WEB_Emergencias/Links_del_ Cuerpo_Principal/Volcanes/Informe\%5C\%20Riesgo\% 5C\%2OVolcanico.htm (visited on 11/21/2020).

Viramonte, J. G., R. J. Sureda, and F. N. R. (1974b). Estado Volcánico de la Isla Decepción, Islas Shetland del Sur, Antártida Argentina. Contribución del Instituto Antártico Argentino. Buenos Aires, Argentina.

Wilson, T., C. Stewart, H. Bickerton, P. Baxter, A. V. Outes, G. Villarosa, and E. Rovere (2013). Impacts of the June 2011 Puyehue-Cordón Caulle volcanic complex eruption on urban infrastructure, agriculture and public health. Institute of Geology and Nucelar Sciences, pp. 1-88. 